\title{
Speech Acts and Its Translation Accuracy in Bilingual Fables
}

Usep Muttaqin ${ }^{1}$, Nadia Gitya Yulianita ${ }^{2}$, Uki hares Yulianti ${ }^{3}$

123Faculty of Humanities, Jenderal Soedirman University

usep.muttaqin@unsoed.ac.id ${ }^{1}$, nadiagityay@unsoed.ac.id² ${ }^{2}$, ukihares@unsoed.ac.id ${ }^{3}$

Article History:

First Received:

$05 / 12 / 2020$

Final Revision:

$22 / 12 / 2020$

Available online:

$30 / 12 / 2020$

\begin{abstract}
The study aims to analyze the type of speech act found in bilingual fables and its translation accuracy. The theory of Searle (1969) on the classification of speech act and the instrument of translation accuracy from Nababan et. al. (2012) are used in the study. It is a descriptive qualitative research with embedded-case study. Several fables books from several different publishers are taken as the data source. The result shows that there are seven pairs of speech act found in both SL and TL utterances, namely directive - directive, representative - representative, expressive - expressive, commissive - commissive, directive - representative, expressive representative, and expressive directive. The first four pairs are in the same type of speech act whereas the last three pairs have different types of speech acts between SL and TL utterances. Those pairs with the same type of speech act are mostly translated accurately while those pairs with different type of speech act are translated less accurately and inaccurately.
\end{abstract}

Keywords: fables; speech act; translation accuracy; translating utterances

\section{http://jos.unsoed.ac.id/index.php/jes}

\section{INTRODUCTION}

Fable is a short story, in prose or verse, which provides an example of an abstract moral thesis or principle of human behavior in which animals speak and act like the type of human type they represent (Abrams, 2005). Fables usually tell about something that does not really happen, but it usually contains moral messages that are very well known to the children who read them. As a multi-ethnic country, Indonesia is very rich in the diversity of fables. For example, we are very familiar with the tales of Si Kancil, Si Kura-kura, Ikan Mas and so on. These stories are widely known in Indonesian society through oral stories and from books. These stories also provide moral messages that are very good for children to know. Delivering this moral message through fables is considered effective because the message is conveyed lightly in the form of a story.

Apart from introducing stories and moral messages, fables also contain local wisdom from the area where the story is originated. Local wisdom, which is an accumulation of knowledge and policies that grow and develop in a community that 
summarizes this theological, cosmological, and sociological perspective, deserves to be introduced to the Indonesian people and international readers (Afiqoh et al., 2018). Therefore, it is necessary to translate and rewrite the story into English and other languages.

Translation and rewriting of fables into other languages with different cultures, such as Indonesian and English, often encounter various obstacles. One of which is meaning equivalence. Translation is an activity to transfer a text's meaning into another language following the author's intent (Newmark, 1988). In the process of translating, a translator is required not only to be able to transfer meaning from the source language (SL) into the target language (TL) but also to be able to display the existing equivalences between SL and TL so that what the SL writer says can be conveyed properly in TL. In other words, the translator must be able to transfer the message into TL accordingly and without any distortion in meaning from the SL message.

To be able to convey this meaning from SL into TL, a translator needs to translate the text accurately. This means that the text translated into TL has the same meaning and message as the text in SL (Nababan et al., 2012). Consider the following example of an accurate and not accurate translation:

Table 1. Examples of Translation Accuracy

\begin{tabular}{|c|c|c|}
\hline & SL & TL \\
\hline (1) & $\begin{array}{l}\text { "Ah...Ibu pasti hanya ingin } \\
\text { menakut-nakutiku saja." }\end{array}$ & $\begin{array}{l}\text { "Ah...Surely Mom just want } \\
\text { to scare me." }\end{array}$ \\
\hline (2) & $\begin{array}{l}\text { "Sebenarnya kalau kamu mau } \\
\text { meminta hatiku tak perlu harus } \\
\text { membunuhku" }\end{array}$ & $\begin{array}{l}\text { "Actually if you want to ask } \\
\text { my heart does not have to } \\
\text { kill me" }\end{array}$ \\
\hline
\end{tabular}

Example (1) shows an accurate translation from SL into TL. The translator transfers the meaning accurately with no distortion in meaning. The meaning is easily understood in TL text as it is in SL text. On the other hand, example (2) shows an inaccurate translation. This inaccurate translation is based on two reasons. First, there is a reduction of meaning in TL text. The translator does not transfer the meaning of word you from SL to TL. Due to the differences between SL and TL grammatical rules, this word you or kamu which is delivered implicitly in SL should be written explicitly in TL. If it is written explicitly, the complete SL text would be sebenarnya kalau kamu mau meminta hatiku (kamu) tak perlu harus membunuhku. Therefore, the clause (kamu) tak perlu harus membunuhku should be translated as you do not have to kill me. The second reason is that translator does not transfer the meaning of the word hati from SL to TL accurately. Hati here actually means an organ or part of a body which should be translated as liver in TL text. This inaccurate translation shows that the translator does not convey the meaning intended by the author of SL.

Fables usually consist of many direct speeches that are uttered by the character of the story. In order to translate these utterances, a translator also needs to pay attention to speech acts. Speech act is actions performed by producing an utterance (Yule, 1997). It contains of three related acts, namely a locutionary acts, illocutionary acts, and perlocutionary acts (Austin, 1975). The first refers to the basic act of the 
utterance, the second refers to acts performed via utterances, while the last refers to the effect that an utterance has. Furthermore, Searle (1969) classifies the speech act into five types: representatives, directives, commissive, expressive, and declaration. Understanding all these kinds of speech acts can help a translator to transfer the meaning from SL utterances into TL utterances because translation is not only the process of meaning transfer but also the process of intention transfer (Setyaji, 2014). Here are some examples:

Table 2. Examples of Speech Acts in Translating Utterances

\begin{tabular}{|c|c|c|c|c|c|}
\hline & SL & $\begin{array}{l}\text { Speech } \\
\text { Acts }\end{array}$ & TL & $\begin{array}{l}\text { Speech } \\
\text { Acts }\end{array}$ & Accuracy \\
\hline (3) & $\begin{array}{lr}\text { "Aku } & \text { sedih, } \\
\text { karena aku gak } \\
\text { punya sahabat } \\
\text { seperti } \quad \text { yang } \\
\text { lain" jawab } \\
\text { kambing. }\end{array}$ & (expressive) & $\begin{array}{l}\text { "l am sad, } \\
\text { because } \text { I } \\
\text { don't have } \\
\text { friend like the } \\
\text { others" } \\
\text { answered } \\
\text { sheep. }\end{array}$ & (expressive) & accurate \\
\hline (4) & $\begin{array}{l}\text { "Keterlaluan } \\
\text { kamu bebek!" }\end{array}$ & (expressive) & $\begin{array}{l}\text { "How much } \\
\text { you duck" }\end{array}$ & (directive) & $\begin{array}{c}\text { not } \\
\text { accurate }\end{array}$ \\
\hline
\end{tabular}

Example (3) shows an accurate translation where the translator transfers not only the meaning but also the speech acts of SL utterances into TL utterances. The SL contains of an expressive act where the speaker expressed his sadness of not having a friend and it is translated into TL as the same act. Example (4), however, shows that the translator transfers the speech act from SL into TL as different kinds of speech acts. SL utterances contains an expressive speech act where the speaker expressed his upsetting feeling towards the hearer whereas the TL is a directive speech act in the form of a question. This translation is considered as an inaccurate translation.

In assessing the accuracy of the translated utterances, the theory of Nababan et al. (2012) is also used as the instrument to rate the level of accuracy of translated utterances. The instrument can be seen in the table below.

Table 3. The Instrument of Translation Accuracy (Nababan et al., 2012)

\begin{tabular}{ccl}
\hline $\begin{array}{c}\text { Translation } \\
\text { Category }\end{array}$ & Score & \multicolumn{1}{c}{ Qualitative Parameter } \\
\hline Accurate & 3 & $\begin{array}{l}\text { The meaning of words, technical terms, phrases, } \\
\text { sentences or SL text is translated accurately into } \\
\text { TL without any distortion in meaning }\end{array}$ \\
\hline Less Accurate & 2 & $\begin{array}{l}\text { Most of the meanings of words, technical terms, } \\
\text { phrases, clauses, sentences, or SL texts are } \\
\text { accurately translated to the TL. However, there } \\
\text { are still distortions in the meaning or translation } \\
\text { of multiple meanings, or the meaning is omitted, } \\
\text { which disturbs the message's integrity. }\end{array}$ \\
\hline
\end{tabular}




\begin{tabular}{ll} 
Not accurate 11 & $\begin{array}{l}\text { The meaning of words, technical terms, phrases, } \\
\text { clauses, sentences, or source language texts are } \\
\text { inaccurately translated to the target language or } \\
\text { deleted. }\end{array}$ \\
\hline
\end{tabular}

The example (3) is rated as an accurate translation since all the meaning of words and phrases are translated accurately into TL without any distortion in meaning, while the example (4) is rated as a less accurate translation since there is a distortion in meaning. The SL utterances contains a representative speech act, but it is translated into TL as a directive speech act. These examples above show us the importance of considering speech acts in translating utterances from SL into TL to help achieve an accurate translation.

There have been several studies conducted by other researchers on the topic of speech act and translation accuracy such as Lengari et al. (2019), Syafitri (2019), Orin \& Issy (2016), and Sugiharti (2018). Lengari (2019) focused on analyzing the accuracy of directive speech acts of command turn taking utterances in Game of Thrones novel written by George R. R. Martin published in 1996 and its translation entitled Perebutan Tahta published in 2015, Sugiharti (2018) analyzed the translation of directive speech acts in The Old Man and The Sea novel by Ernest Hemingway published in 1952 and its translation entitled Lelaki Tua dan Laut published in 1973, whereas Syafitri (2019), and Orin \& Issy (2016) focused only on analyzing speech act with no relation to translation. In summary, most of them only focus on one type of speech act, and none of them analyze the speech act in bilingual fables utterances and its translation accuracy. Therefore, this study is worth conducting.

\section{RESEARCH METHOD}

This study aims to identify, analyze, and describe speech acts found in bilingual (Indonesia-English) fables and its translation accuracy. It is qualitative descriptive research that, in its implementation, relies on humans (researchers) as data collectors. Sources of data used in this research are bilingual (Indonesian-English) fable books from several publishers, including Daffa Media, Lingkar Media, Cahaya Agency, Bintang Indonesia, and HNH publishers. They publish a lot of bilingual fables. The research strategy used is an embedded case study in which the study only focuses on a certain aspect. In this case, it focuses on speech acts and its translation accuracy. The data of this study are focused on direct sentences or utterances uttered by characters in the story. Researchers collected data in the form of utterances; they then described, analyzed, and classified them based on the type of speech act found in both SL and TL utterances.

In this study, researchers used a purposive sampling technique that led to the cases examined in this study, namely the speech acts in both SL and TL texts. The data collection technique used is the note-taking method. The researcher read, recorded, and compared existing data. In analyzing the data, a comparative method was used to compare the source language and the target language by taking into account the speech act translated into TL and also the accuracy of the translation. 


\section{RESULT AND DISCUSSION}

From 149 data analyzed in this study, it is found that there are seven pairs of speech acts used by characters in bilingual fables. They are directive - directive, representative - representative, expressive - expressive, commissive - commissive, representative - directive, expressive - representative, and expressive - directive. Four pairs of them are in the same kinds of speech acts, while the other three pairs have different kinds of speech act in SL and TL text.

Table 4. Kinds of Speech Acts Found in Bilingual Fables

\begin{tabular}{lccc}
\hline \multicolumn{1}{c}{ Kinds of Speech Acts } & TL & Frequency & Percentage \\
\hline Directive & Directive & 56 & \\
\hline Representative & Representative & 53 & $37.6 \%$ \\
\hline Expressive & Expressive & 25 & $35.6 \%$ \\
\hline Commissive & Commissive & 11 & $16.7 \%$ \\
\hline Expressive & Directive & 2 & 7.4 \\
\hline Expressive & Representative & 1 & $1.3 \%$ \\
\hline Directive & Representative & 1 & $0.7 \%$ \\
\hline \multicolumn{1}{c}{ Total } & & $\mathbf{1 4 9}$ & $\mathbf{1 0 0 . 0 0 \%}$ \\
\hline
\end{tabular}

Directive is a kind of speech act that is used to get someone else to do something (Yule, 1997). This speech act can contain act such as suggestion, request, order, command, and so on. It is the most frequently used speech act in the data. There are 56 data or $37.6 \%$ of the total data found containing this directive speech act in both SL and TL text.

Table 5. Example of Directive Speech Act in Both SL and TL Utterances

\begin{tabular}{|c|c|c|c|c|c|}
\hline & SL & $\begin{array}{c}\text { Speech } \\
\text { Acts }\end{array}$ & TL & $\begin{array}{c}\text { Speech } \\
\text { Acts }\end{array}$ & $\begin{array}{c}\text { Score of } \\
\text { Accuracy }\end{array}$ \\
\hline (5) & $\begin{array}{l}\text { "serigala, tolong } \\
\text { jangan makan } \\
\text { aku" pinta anak } \\
\text { kambing }\end{array}$ & (directive) & $\begin{array}{l}\text { "wolf, please } \\
\text { do not eat me" } \\
\text { ask the goat } \\
\text { lamb. }\end{array}$ & (directive) & 3 \\
\hline (6) & $\begin{array}{l}\text { "Bagaimana } \\
\text { sahabatku, apa } \\
\text { kamu takut?" } \\
\text { tanya buaya. }\end{array}$ & (directive) & $\begin{array}{l}\text { "How is my } \\
\text { friend, are } \\
\text { you afraid?" } \\
\text { asked the } \\
\text { crocodile. }\end{array}$ & (directive) & 2 \\
\hline (7) & $\begin{array}{l}\text { "bisakah kau } \\
\text { memenuhi } \\
\text { permintaanku } \\
\text { suamiku" ucap } \\
\text { istrinya }\end{array}$ & (directive) & $\begin{array}{l}\text { "can you meet } \\
\text { my husband's } \\
\text { request" said } \\
\text { his wife }\end{array}$ & (directive) & 1 \\
\hline
\end{tabular}

Example (5), (6), and (7) show the directive speech acts found in both texts. Example (5) contains an act of prohibition where the speaker instructs the hearer 
not to do something, in this case not to eat him. Both the SL and TL text have the same meaning of this prohibition. Example (6) contains an act of asking a question. The speaker asked his friend whether he is afraid or not. In example (7), the speaker performs the act of request to the hearer. The speaker, in this case a wife, asked her husband whether he could meet her request or not.

In term of the translation accuracy, these three examples have different score. Example (5) shows an accurate translation where the translator transfers the meaning accurately from SL into TL without any meaning distortion. Example (6) shows a less accurate translation since utterance bagaimana sahabatku, apa kamu takut? in SL is translated as how is my friend, are you afraid? in TL. The SL utterances only asks one thing. It is about whether the hearer is afraid or not. However, the TL utterances asks two things. It does not only ask about whether the speaker is afraid, it also asks about a friend. This addition of message in TL utterances lessens the accuracy of the translation.

Example (7) shows an inaccurate translation. Both SL and TL texts contain the act of request, but the meaning is different. The SL text shows the request from a wife to a husband. The wife asked the husband whether he could meet her request. On the other hand, the TL text shows a request from a wife to the hearer whether he/she can meet her husband's request. This change in meaning from SL to TL shows the inaccurate translation of the utterance in example (7).

Table 6. The Accuracy of Directive Speech Act Translation

\begin{tabular}{cc}
\hline $\begin{array}{c}\text { Score of } \\
\text { Accuracy }\end{array}$ & Frequency \\
\hline 3 & 30 \\
\hline 2 & 17 \\
\hline 1 & 9 \\
\hline Total & $\mathbf{5 7}$ \\
\hline
\end{tabular}

From all 57 data categorized as directive speech act, 30 data of them are categorized as accurate translation, 18 data are less accurate translation, and 9 data are inaccurate translation. It is clear that the majority of the utterances in this type of speech acts are translated accurately into TL.

Representative is the kind of speech acts that state what the speaker believes to be the case (Yule, 1997). It includes assertions, statement of fact, description, and conclusion. There are 53 data utterances or $35.6 \%$ of the total data containing this representative speech act in both SL and TL. The example of the data can be seen in the table below.

Table 7. Examples of Representative Speech Acts in Both SL and TL Utterances

\begin{tabular}{lllllc}
\hline \multicolumn{1}{c}{ SL } & Speech Acts & \multicolumn{1}{c}{ TL } & Speech Acts & $\begin{array}{c}\text { Score of } \\
\text { Accuracy }\end{array}$ \\
\hline (8) & $\begin{array}{l}\text { "Iya, aku ingin } \\
\text { menjadi } \\
\text { pangeran di drand } \\
\text { hutan ini." kata }\end{array}$ & $\begin{array}{l}\text { "Yes, I want } \\
\text { to be a } \\
\text { prince in the } \\
\text { forest." said } \\
\text { Turtle. }\end{array}$ & (representative) & 3 \\
\hline
\end{tabular}




\begin{tabular}{|c|c|c|c|c|c|}
\hline & $\begin{array}{l}\text { seekor Kura- } \\
\text { kura. }\end{array}$ & & & & \\
\hline (9) & $\begin{array}{l}\text { "Akulah } \\
\text { kepompong } \\
\text { yang beberapa } \\
\text { hari yang lalu } \\
\text { kau ejek dan } \\
\text { kau kasihani" } \\
\text { ujar kupu-kupu } \\
\text { cantik itu }\end{array}$ & (representative) & $\begin{array}{l}\text { "I'm the } \\
\text { cocoon that a } \\
\text { few days ago } \\
\text { you mocked } \\
\text { and you } \\
\text { dared" said } \\
\text { the beautiful } \\
\text { butterfly }\end{array}$ & (representative) & 2 \\
\hline (10) & $\begin{array}{l}\text { "Sebenarnya } \\
\text { kalau kamu } \\
\text { mau meminta } \\
\text { hatiku tak } \\
\text { perlu harus } \\
\text { membunuhku" }\end{array}$ & (representative) & $\begin{array}{l}\text { "Actually if } \\
\text { you want to } \\
\text { ask my heart } \\
\text { does not } \\
\text { have to kill } \\
\text { me" }\end{array}$ & (representative) & 1 \\
\hline
\end{tabular}

Example (8), (9), and (10) show the representative speech act found in both SL and TL text. Example (8) shows an assertion where the speaker, the turtle, stated that he wanted to be a prince in the forest. In example (9), the speaker claimed that he was the cocoon that was mocked by the hearer a few days ago. In example (10) the speaker stated that the hearer did not need to kill him if he wanted to have his liver. These acts of stating and claiming are part of representative speech act.

For the accuracy of the translation, example (8) is the accurate one since the translator is be able to transfer the SL meaning accurately into the TL utterance. However, example (9) shows a less accurate translation. The word kasihani in SL text is translated as dared in TL which is not equivalent in meaning. Dared has the meaning be brave or rude while kasihani has the meaning of pity. Example (10) shows an inaccurate translation. The word hati in SL which actually means liver is translated as heart in TL. The TL text is also lack of subject for the clause does not have to kill me.

Table 8. The Accuracy of Representative Speech Act Translation

\begin{tabular}{cc}
\hline $\begin{array}{c}\text { Score of } \\
\text { Accuracy }\end{array}$ & Frequency \\
\hline 3 & 19 \\
\hline 2 & 24 \\
\hline 1 & 10 \\
\hline Total & $\mathbf{5 3}$ \\
\hline
\end{tabular}

Overall, the translation accuracy of representative speech act can be summarized in the table 8 . There are 19 utterances that are translated accurately into TL out of the 53 of the totals. However, 24 data are categorized as less accurate translation, and 10 data are inaccurate translation.

Expressive is the kind of speech act that express the phycological states of the speaker such as likes, dislikes, pain, pleasure, joy, and sorrow (Yule, 1997). There 
are 25 data or $16.7 \%$ of the total data containing this expressive speech act on both SL and TL texts. Here are several examples of them:

Table 9. Examples of Expressive Speech Acts in both SL and TL Utterances

\begin{tabular}{|c|c|c|c|c|c|}
\hline & SL & Speech Acts & TL & Speech Acts & $\begin{array}{l}\text { Score of } \\
\text { Accuracy }\end{array}$ \\
\hline (11) & $\begin{array}{l}\text { "Horeee...kita } \\
\text { dapat } \\
\text { semangka, } \\
\text { Kuda!" seru } \\
\text { jerapah. }\end{array}$ & (expressive) & $\begin{array}{l}\text { "Yippee we got } \\
\text { watermelon, } \\
\text { Horse!" shout } \\
\text { Giraffe. }\end{array}$ & (expressive) & 3 \\
\hline (12) & $\begin{array}{l}\text { "Aduh...sakit } \\
\text { sekali, apa } \\
\text { ini...!" ucap } \\
\text { anak ikan } \\
\text { kesakitan. }\end{array}$ & (expressive) & $\begin{array}{l}\text { "Ahhhh...it hurt, } \\
\text { what is this...!" } \\
\text { said the fish kid } \\
\text { in pain. }\end{array}$ & (expressive) & 2 \\
\hline (13) & $\begin{array}{l}\text { Keterlaluan } \\
\text { kamu bebek!" }\end{array}$ & (expressive) & $\begin{array}{l}\text { "How much you } \\
\text { duck" }\end{array}$ & (expressive) & 1 \\
\hline
\end{tabular}

In example (11) the speaker expresses his joy of getting a watermelon. The word horeee in SL text and Yippee in TL text express this feeling of joy or delight. The utterance in example (12) contains an expression of pain. The word aduh and sakit in SL also the word ahhhh and hurt in TL express the feeling of pain that is felt by the speaker of the utterance. In example (13) the speaker expresses his feeling of annoyed toward the hearer. All these feelings expressed in example (11), (12, (13) makes them categorized as expressive speech act.

In addition, the examples above are rated differently in terms of translation accuracy. Example (11) is rated as an accurate translation since the translator successfully transfers the meaning from SL text into TL text along with the expressive speech act. The example (12), however, is rated as a less accurate translation. The word sekali that modifies the word sakit in SL is not translated into TL. Therefore, there is deletion of meaning in TL text. Also, the word hurt in TL is not translated properly in terms of grammar. It should be translated as hurts based on the grammar of TL text.

Table 10. The Accuracy of Expressive Speech Act Translation

\begin{tabular}{cc}
\hline $\begin{array}{c}\text { Score of } \\
\text { Accuracy }\end{array}$ & Frequency \\
\hline 3 & 17 \\
\hline 2 & 5 \\
\hline 1 & 3 \\
\hline Total & $\mathbf{2 5}$ \\
\hline
\end{tabular}

From all 25 data containing expressive speech act in both SL and TL utterances, most of the data, 17 utterances, are categorized as accurate translation. However, there are still 5 data categorized as less accurate translation, and 3 data are as inaccurate translation. 
Commissive is the kind of speech act that speakers use to commit themselves to some future action that include promises, threats, refusals, pledges, and so on (Yule, 1997). It is found that 11 data or $7.4 \%$ of total data analyzed containing this commissive speech act in both SL and TL texts. The example can be seen in the table below.

Table 11. Examples of Commissive Speech Acts in both SL and TL Utterances

\begin{tabular}{|c|c|c|c|c|c|}
\hline & SL & Speech Acts & TL & Speech Acts & $\begin{array}{c}\text { Score of } \\
\text { Accuracy }\end{array}$ \\
\hline (14) & $\begin{array}{l}\text { "Aku pasti akan } \\
\text { memenangkan } \\
\text { sayembara ini." } \\
\text { Ketus Jerapah } \\
\text { kepada binatang } \\
\text { yang Iain }\end{array}$ & (commissive) & $\begin{array}{l}\text { "l will } \\
\text { definitely win } \\
\text { this contest." } \\
\text { snapped } \\
\text { Giraffe to other } \\
\text { animals. }\end{array}$ & (commissive) & 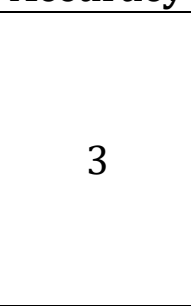 \\
\hline (15) & $\begin{array}{l}\text { "Baiklah istriku, } \\
\text { aku akan } \\
\text { menuruti } \\
\text { permintaanmu" } \\
\text { ucap buaya }\end{array}$ & (commissive) & $\begin{array}{l}\text { "Well my wife, } \\
\text { I will obey } \\
\text { your request" } \\
\text { said crocodile }\end{array}$ & (commissive) & 2 \\
\hline (16) & $\begin{array}{l}\text { "Kalau kalian } \\
\text { tidak bersedia, } \\
\text { aku sendiri yang } \\
\text { akan } \\
\text { melawannya } \\
\text { dengan } \\
\text { menggelembung } \\
\text { kan badanku ini" }\end{array}$ & (commissive) & $\begin{array}{l}\text { "If you do not } \\
\text { want me, I'll } \\
\text { fight him by } \\
\text { inflating my } \\
\text { body" }\end{array}$ & (commissive) & 2 \\
\hline
\end{tabular}

The speaker of utterance in example (14) makes a promise that he will definitely win the contest. This promise is expressed in both SL and TL text. In example (15), the speaker, in this case the crocodile, commits himself to fulfill his wife request. Example (16) also shows the commissive speech act where the speaker, frog, commits himself to fight cow by inflating his body. All these examples show the commissive speech act in both texts.

The three examples above are rated as accurate and less accurate translation. Example (14) is an accurate translation since the translator is able to transfer the meaning accurately from SL to TL along with its commissive speech act. On the other hand, example (15) and (16) are rated as less accurate translation. In example (15) the translator does not transfer the meaning of the phrase menuruti permintaanmu accurately. The translator chooses the word obey in TL which is not equivalent in meaning with its SL text.

Example (16) is also categorized as less accurate translation since there is a change in focus between the SL and TL text. The context of this utterance is that the speaker, the frog, asked his friend to fight the cow, but his friends refused. The clause kalau kalian tidak bersedia, which is based on the context means that if you do not want to fight, is translated into TL as if you do not want me. It can be seen that the 
focus of the utterance changes from SL to TL. In SL it means does not want to fight, but in TL it means does not want me. This leads the researchers to categorize it as a less accurate translation. In addition, the overall translation accuracy of this commissive speech act is that from 11 data six of them are categorized as accurate translation, while 5 data are categorized as less accurate translation.

Table 12. The Accuracy of Commissive Speech Act Translation

\begin{tabular}{cc}
\hline $\begin{array}{c}\text { Score of } \\
\text { Accuracy }\end{array}$ & Frequency \\
\hline 3 & 6 \\
\hline 2 & 5 \\
\hline 1 & 0 \\
\hline Total & $\mathbf{1 1}$ \\
\hline
\end{tabular}

The four previous speech acts explained are those speech acts with the same type found between SL and TL text. The next three examples below are the type of speech acts that are different between SL and TL text. The first is directive - representative. It means that the directive speech act in SL is translated as representative speech act in TL. There is only one data categorized into this type as can be seen in example (17).

Table 13. Different Speech Acts found between SL and TL Utterances

\begin{tabular}{|c|c|c|c|c|c|}
\hline & SL & Speech Acts & TL & Speech Acts & $\begin{array}{l}\text { Score of } \\
\text { Accuracy }\end{array}$ \\
\hline (17) & $\begin{array}{l}\text { " Anakku jika aku } \\
\text { mati kuburkan } \\
\text { aku dekat sungai } \\
\text { ini saja" }\end{array}$ & (directive) & $\begin{array}{l}\text { ""My son if I } \\
\text { die to bury me } \\
\text { near this } \\
\text { river" }\end{array}$ & $\begin{array}{c}\text { (representati } \\
\text { ve) }\end{array}$ & 2 \\
\hline (18) & $\begin{array}{lr}\text { "Wah...ada } & \text { cacing } \\
\text { nih, kelihatannya } \\
\text { sangat } & \text { lezat. } \\
\text { Kebetulan sekali } \\
\text { aku sudah lapar. } \\
\text { Memang benar } \\
\text { ya, kalau rejeki } \\
\text { itu tak akan } \\
\text { kemana-mana." } \\
\text { Ucap si anak ikan }\end{array}$ & (expressive) & $\begin{array}{l}\text { "Wow... a } \\
\text { worm, looks so } \\
\text { delicious. } \\
\text { Coincidence, } \\
\text { I'm very } \\
\text { hungry. Truth } \\
\text { that if it's my } \\
\text { luck it won't } \\
\text { go anywhere." } \\
\text { Said the fish } \\
\text { kid. }\end{array}$ & $\begin{array}{c}\text { (representati } \\
\text { ve) }\end{array}$ & 1 \\
\hline (19) & $\begin{array}{l}\text { "Melihat kuburan } \\
\text { ibunya terbawa } \\
\text { arus, anak katak } \\
\text { itu menangis } \\
\text { dengan keras } \\
\text { mencari-cari } \\
\text { kubiran ibunya, } \\
\text { "Sungai jangan }\end{array}$ & (expressive) & $\begin{array}{l}\text { Seeing her } \\
\text { mother's grave } \\
\text { carrying the } \\
\text { current, the } \\
\text { boy frogs } \\
\text { loudly } \\
\text { searching for } \\
\text { his mother's }\end{array}$ & (directive) & 1 \\
\hline
\end{tabular}




\begin{tabular}{ll}
\hline kau bawa ibuku" & grave, "The \\
teriaknya & river do not \\
& you take my \\
& mother" he \\
& cried " \\
\hline
\end{tabular}

The SL utterances of example (17) is a directive speech act that contains an act of a request from a mother to her son. The mother asked her son to bury her near the river when she died. However, the TL utterances lost its directive act. The translator seems fail to deliver the act of request from SL to TL utterances. The TL utterance only shows the act of an assertion that if the mother died, the son would bury her near the river. This loss of request act from SL to TL also makes the translation categorized as a less accurate translation.

Another different pair of speech act found is expressive - representative. Example (18) also shows that the utterance in SL text is an expressive speech act where the speaker expresses his joy or delight of finding a worm and that it is his luck to be able to find it. On the other hand, the speech act in TL is categorized as representative. The speaker states that if it was his luck, he would definitely find the worm. The example (18) is also categorized as inaccurate translation since the translator transfers the meaning too literally. The translator writes if it's my luck it won't go anywhere. From the context, it can be seen that what the speaker means is that if it was his luck, he would definitely find the worm. Also, the different of speech act between two texts confirms the inaccuracy of the translation.

The last different pair of speech act found is expressive - directive. The expressive speech act in SL is translated as directive speech act in TL. There are two utterances categorized as this type of speech act, they are example (4) and (19). In example (19) the utterance sungai jangan kau bawa ibuku in SL is the speaker's expression of sadness since the grave of his mother was washed away by the river. On the other hand, the utterance in TL text is a directive speech act where the speaker orders the river not to take his mother grave. This different speech act makes example (19) can be categorized as inaccurate translation. In addition, in terms of accuracy, the translator also transfers the meaning of the word bawa from SL into TL too literally. It seems that the translator does not consider the context of the utterance. The word bawa here means "wash away". Therefore, the meaning between the SL and the TL text is different that confirms the inaccuracy of the translation.

\section{CONCLUSION}

The study reveals the types of speech acts found in bilingual fables and their translations' accuracy. The fables were selected randomly from five publishers in Indonesia. From those fables, four types of speech acts and their translations were found, namely directive, representative, expressive, and commissive. Those speech acts were translated into the same type of speech act in TL. However, there are also three types of speech act which were not translated into the same type in TL. The first type is expressive which was translated into directive. There is also expressive which was translated into representative. Lastly, directive was translated into representative. The result of the analysis shows that the majority of utterances with 
the same type of speech act in both SL and TL are translated accurately, whereas all the utterances with different types of speech act are translated less accurately and inaccurately. Therefore, it is important for a translator to consider speech act when translating utterances as one of the ways to be able to produce an accurate translation.

\section{REFERENCES}

Abrams, M. H. (2005). A Glossary of Literary Terms. Michael Rosenberg.

Afiqoh, N., Atmaja, H. T., \& Saraswati, U. (2018). Penanaman Nilai Kearifan Lokal dalam Pembelajaran Sejarah Pokok Bahasan Perkembangan Islam di Indonesia Pada Siswa Kelas X IPS di SMA Negeri 1 Pamotan Tahun Ajaran 2017/2018. Indonesian Journal of History Education, 6(1). https://journal.unnes.ac.id/sju/index.php/ijhe/article/view/27353

Austin, J. L. (1975). How to Do Things with Words. Harvard University Press.

Lengari, Y. G. P., Nababan, M. R., \& Djatmika, D. (2019). The Accuracy of Directive Speech Act Responding Command Turn Taking in Game of Thrones Novel. International Journal of Multicultural and Multireligious Understanding, 6(2), 472. https://doi.org/10.18415/ijmmu.v6i2.717

Nababan, M., Nuraeni, A., \& Sumardiono. (2012). Pengembangan Model Penilaian Kualitas Terjemahan. Kajian Linguistik Dan Sastra, 24(1), 39-57.

Newmark, P. (1988). A Textbook of Translation. Prentice Hall.

Orin, K., \& Issy, Y. (2016). Representative speech Acts Perfomed by the debaters in an English Debate Competetion. English Education Journal, 6(2), 79-86. https://journal.unnes.ac.id/sju/index.php/eej/article/view/13059

Searle, J. R. (1969). Speech Acts: An Essay in the Philosophy of Language. Cambridge University Press.

Setyaji, A. (2014). How Speech Acts Work in Translation: An Analysis on Speech ACts Tranlating A Script of Titanic Film. PRASASTI: Journal of Linguistics, 3(1), 1431. https://doi.org/https://doi.org/10.20961/prasasti.v3i1.344

Sugiharti, S. (2018). Translation Analysis of Directive Speech Acts in The Old Man And The Sea Novel and Its Translation into Indonesia. Jurnal Cahaya $\begin{array}{lll}\text { Pendidikan, } & \text { 4(1), }\end{array}$ https://doi.org/http://dx.doi.org/10.33373/chypend.v4i1.1284

Syafitri, W. (2019). An Analysis of Commissive Speech Act Used by The Shopping Hosts of MNC Shop. Jurnal Arbitrer, 6(1), 28. https://doi.org/10.25077/ar.6.1.28-34.2019

Yule, G. (1997). Pragmatics (H. G. Widdowson (ed.)). Oxford University Press. 